\title{
Hochuekkito, a Kampo (Traditional Japanese Herbal) Medicine, and its Polysaccharide Portion Stimulate G-CSF Secretion from Intestinal Epithelial Cells
}

\author{
Tsukasa Matsumoto ${ }^{1,2}$, Michiyo Moriya ${ }^{1}$, Hiroaki Kiyohara ${ }^{1,2}$, Yoshiaki Tabuchi ${ }^{3}$ and \\ Haruki Yamada ${ }^{1,2}$
}

${ }^{1}$ Kitasato Institute for Life Sciences \& Graduate School of Infection Control Sciences, Kitasato University, Tokyo 108-8641, ${ }^{2}$ Oriental Medicine Research Center, The Kitasato Institute, Tokyo 108-8642 and ${ }^{3}$ Life Science Research Center, University of Toyama, Toyama 930-0194, Japan

\begin{abstract}
Kampo (traditional Japanese herbal) medicines are taken orally due to which the gastric mucosal immune system may act as one of the major targets for the expression of pharmacological activity. The inner surface of the intestinal tract possesses a large area of mucosal membranes, and the intestinal epithelial cells sit at the interface between a lumen and a lymphocyte-rich lamina propria. The cross talk that occurs between these compartments serves to maintain intestinal homeostasis, and the cytokine network plays an important role in the cross talk. In this study, the effect of Hochuekkito (HET), one of Kampo medicines, on cytokine secretion of intestinal epithelial cells was investigated. When murine normal colonic epithelial cell-line MCE301 cells were stimulated with HET, the contents of granulocyte colonystimulating factor (G-CSF) in the conditioned medium were significantly increased in dose- and time-dependent manners. The enhanced G-CSF gene transcription in MCE301 cells by the stimulation of HET was observed by RT-PCR. The enhanced G-CSF secretion by HET was also observed in $\mathrm{C} 3 \mathrm{H} / \mathrm{HeJ}$ mice-derived primary cultured colonic epithelial cells. When the HET was fractionated, only the polysaccharide fraction (F-5) enhanced the G-CSF secretion of MCE301 cells, and the activity of F-5 lost after the treatment of periodate that can degrade the carbohydrate moiety. These results suggest that HET enhances secretion of G-CSF from colonic epithelial cells and the polysaccharide is one of the active ingredients of HET. The enhanced G-CSF secretion by HET may partly contribute to the clinically observed various pharmacological activities of HET including immunomodulating activity.
\end{abstract}

Keywords: G-CSF-Hochuekkito-intestinal epithelial cell-Kampo medicines-MCE301 cellpolysaccharide

\section{Introduction}

Hochuekkito (HET; Bu-Zhong-Yi-Qi-Tang in Chinese) is one of the Kampo (traditional Japanese herbal) medicines that consists of 10 component herbs, and well-known

For reprints and all correspondence: Haruki Yamada, Kitasato Institute for Life Sciences, Kitasato University, Tokyo 108-8641, Japan.

Tel: +81-03-5791-6364; Fax: + 81-03-3445-1351;

E-mail: yamada@lisci.kitasato-u.ac.jp
Kampo formulas used as tonic. HET has been used for the treatment and recovery of valetudinarian, who have chronic diseases, tuberculosis, surgery with loss of appetite, mild fever, night sweat, palpitation, fear, restlessness, weak feeble voice, slurred speech and disturbance of vision. This formula has been identified as an effective drug to improve the function of digestive system and to strengthen defensive system against various infections. It has been reported that HET can promote certain biological activities including 
enhancement of natural killer cells and macrophage activity $(1,2)$. It has also been indicated that HET has an inhibitory effect on influenza virus infection via enhancement of host immune responses in virus-infected mice (3). Recently, we have found that orally administered HET enhanced mucosal immune response to the intranasally and orally administered antigens $(4,5)$.

The gut-associated lymphoreticular tissues exist on the intestinal mucosal sites, and play an important role in host defense including IgA response in the mucosal immune system (6). The inner surface of the intestinal tract possesses a large area of mucosal membranes, and the intestinal epithelial cells sit at the interface between a lumen and a lymphocyte-rich lamina propria. Intestinal epithelial cells function not only as a physiological barrier but also as effector/regulator cells of a host's immune responses to foreign substances, including various pathogens and food antigens (7-13).

The cytokine network plays an important role in the inflammatory and immune responses (14-16). Because Kampo medicines are taken orally, the gastric mucosal immune system including intestinal epithelial cells may act as one of the major targets for the expression of pharmacological activity. However, the modulating activity of Kampo medicines on mucosal immune system has not been fully understood. In this study, the effect of HET on the cytokine secretions of intestinal epithelial cells was investigated using murine colonic epithelial cell line MCE301 cells in vitro.

MCE301 has been established by a primary culture of gastric mucosal cells from transgenic mice harboring a temperature-sensitive simian virus 40 large $\mathrm{T}$-antigen gene (17). The cells were not transformed, as judged by the absence of anchorage-independent growth in soft agar and lack of tumor formation in nude mice. Because MCE301 cells have been shown to retain many of the characteristics of normal colonic epithelial cells (17), the studies using MCE301 cells provide useful information to understand colonic epithelial cell function and cellular response to various stimuli.

In the present study, it was found that HET enhanced the granulocyte colony-stimulating factor (G-CSF) secretion from intestinal epithelial cells. Present article deals with the effect of HET on the secretion of G-CSF. To our knowledge, this is a first report on the modulation of cytokine secretion of intestinal epithelial cells by the stimulation of Kampo medicines.

\section{Materials and Methods}

\section{Materials}

Establishment and characterization of murine normal colonic epithelial cell-line MCE301 were reported previously (17). The MCE301 cells were cultured in
Dulbecco's modified Eagle medium/Ham's F-12 (1:1) (DMEM/F-12) medium (Sigma, St Louis, MO, USA) supplemented with $5 \%$ fetal bovine serum (FBS; Sigma), $10 \mu \mathrm{g} \mathrm{ml}^{-1}$ insulin, $5.5 \mu \mathrm{g} \mathrm{ml}^{-1}$ transferrin, $2 \mu \mathrm{g} \mathrm{ml}^{-1}$ ethanolamine, $5 \mathrm{ng} \mathrm{ml}^{-1}$ sodium selenite and $10 \mathrm{ng} \mathrm{ml}^{-1}$ epidermal growth factor at $37^{\circ} \mathrm{C}$ in a humidified atmosphere of $5 \% \mathrm{CO}_{2}$ in air. After reached confluent, the cells were cultured at $39^{\circ} \mathrm{C}$ in DMEM/F-12 alone for 3 days, and then subjected to experiment. All experiments using MCE301 cells were carried out at $39^{\circ} \mathrm{C}$. Phorbol 12 -myristate 13-acetate (PMA) was from Sigma. Calcium ionophore, A23187 was from Calbiochem (La Jolla, CA, USA).

\section{Extract of HET}

Spray-dried extract preparations of HET (TJ-41, Lot No 920041001PO) was kindly supplied by Tsumura \& Co. (Tokyo, Japan). HET for 1-day dose was prepared as follows: a mixture of Astragali Radix (4 g, roots of Astragalus membranaceus Bunge), Atractylodis lanceae Rhizoma (4 g, rhizomes of Atractylodes lancea DC.), Ginseng Radix (4 g, roots of Panax ginseng C.A. Meyer), Angelicae Radix (3 g, roots of Angelica acutiloba Kitagawa), Bupleuri Radix ( $2 \mathrm{~g}$, roots of Bupleurum falcatum L.), Zizyphi Fructus (2 g, fruits of Zizyphus jujuba Miller var. inermis Rehder), Aurantii Bobilis Pericarpium (2 g, pericarps of ripe fruits of Citrus unshu Markovich), Glycyrrhizae Radix (1.5g, roots of Glycyrrhiza uralensis Fisch et DC.), Cimicifugae Rhizoma (1 g, rhizomes of Cimicifuga simplex Worms kjord) and Zingiberis Rhizoma ( $0.5 \mathrm{~g}$, rhizomes of Zingiber officinale Roscoe) was added to water and extracted at $100^{\circ} \mathrm{C}$ for $1 \mathrm{~h}$. The extracted solution was filtered and spray-dried to obtain dry extract powder $(5 \mathrm{~g})$. Chemical profile of HET obtained by the three-dimensional HPLC analysis is shown in Fig. 1.

\section{Animals}

Specific pathogen-free $\mathrm{C} 3 \mathrm{H} / \mathrm{HeJ}$ female mice (6-8 weeks old) were obtained from SLC (Shizuoka, Japan). The mice were maintained under a $24 \mathrm{~h}$ light and dark cycle (12 h of light, $12 \mathrm{~h}$ of darkness) and controlled temperature $\left(23 \pm 1^{\circ} \mathrm{C}\right)$, and they had free access to standard laboratory chow (Oriental Yeast Co., Tokyo, Japan) and water. The procedure from the Prime Minister's Office of Japan (No 6 of March 27, 1980) for the care and use of laboratory animals was followed. The experiments were conducted in accordance with the Guidelines for Animal Use and Experimentation of the Kitasato Institute (Tokyo, Japan), and the approval number of the animal experimentation was 2006-2-35-1 (Kitasato Institute).

\section{Reverse Transcriptase-polymerase Chain Reaction}

Total RNA was extracted from the MCE301 cells using TRIzol $^{\circledR}$ (Invitrogen, Carlsbad, CA, USA), and single 


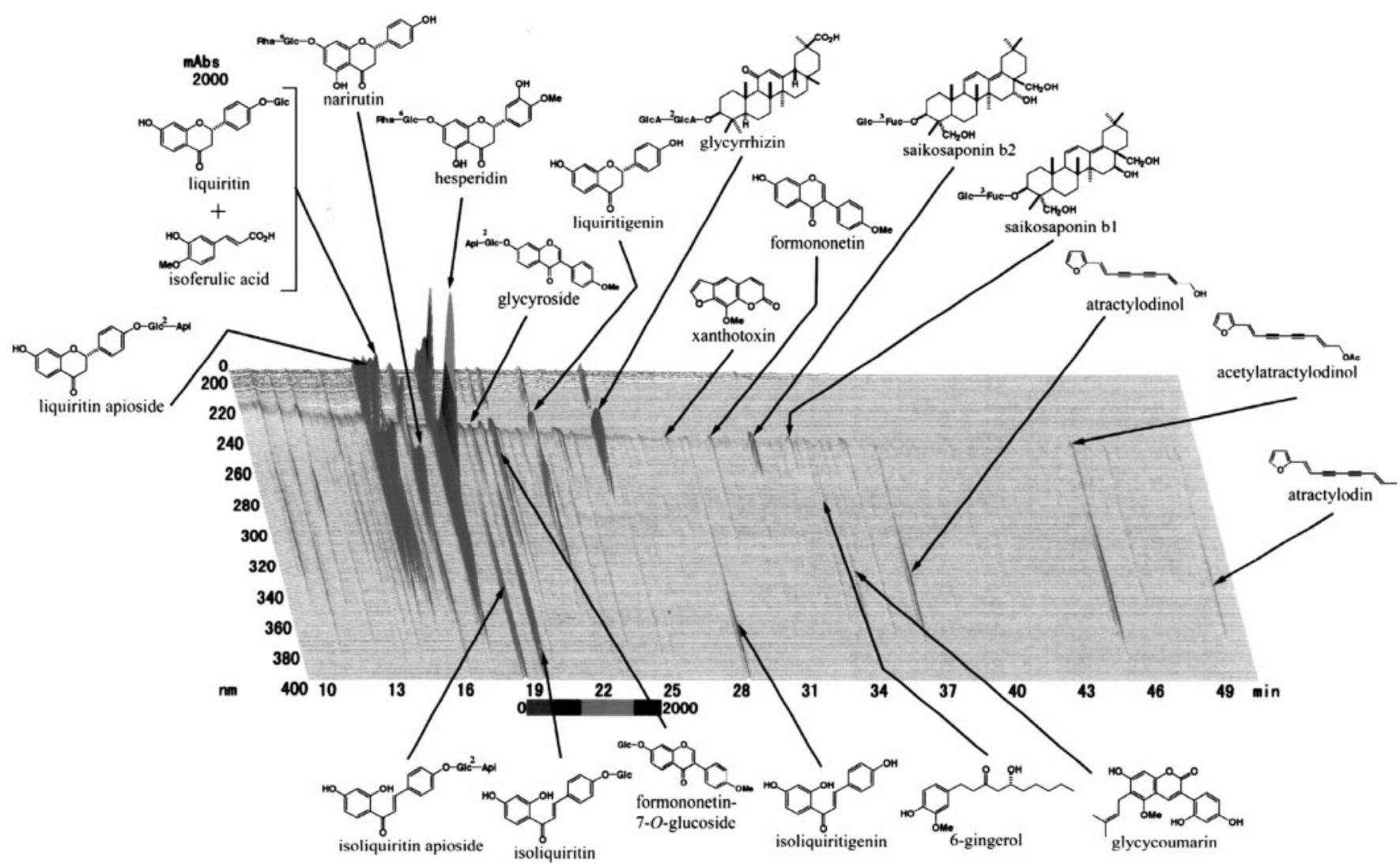

Figure 1. Chemical profile of HET analyzed by three-dimensional HPLC. Each peak of HET in the HPLC profile was identified by comparison of the retention times and UV spectra of chemically defined standard compounds. HPLC condition was as follows: Column; Tosoh TSK GEL ODS80 Ts $(4.6 \times 250 \mathrm{~mm})$. Carrier A: $0.05 \mathrm{M}$ ammonium acetate $(\mathrm{pH} \mathrm{3.6)}$. Carrier B: Acetonitrile. Gradient: $10-100 \%$ carrier B linear in $60 \mathrm{~min}$. Flow

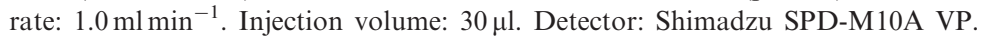

stranded cDNA was generated from $5 \mu \mathrm{g}$ of total cellular RNA using a M-MLV reverse transcriptase (EC 2.7.7.49, ReverTra Ace ${ }^{\circledR}$, Toyobo, Osaka, Japan) according to the instruction manuals. The resulting cDNA was amplified by the polymerase chain reaction (PCR) technique using Taq DNA polymerase (EC 2.7.7.7, Takara, Shiga, Japan) with specific primers. Gene expression of glyceraldehyde-3phosphate dehydrogenase (EC 1.2.1.12, GAPDH) was used as a control. The condition of PCR for G-CSF and GAPDH were as follows: denature at $94^{\circ} \mathrm{C}$ for $30 \mathrm{~s}$, anneal for $30 \mathrm{~s}$ and extend at $72^{\circ} \mathrm{C}$ for $45 \mathrm{~s}$. The annealing temperature was $57^{\circ} \mathrm{C}$. The numbers of cycle were 27 for G-CSF and 16 for GAPDH, respectively. The primer sequences were based on the sequences of the published cDNAs, and were as follows: $5^{\prime}$-gacggctcgcettgctctgcacca- $3^{\prime}$ and $5^{\prime}$ acctggctgccactgtttctttagg-3' for G-CSF, and $5^{\prime}$-gagtatgtcg tggagtctactg- $3^{\prime}$ and $5^{\prime}$-gatgcagggatgatgttctg- $3^{\prime}$ for GAPDH, respectively. PCR products were electrophoresed on a $1.5 \%$ agarose gel, and visualized with ethidium bromide.

\section{Cytokine Protein Array}

A murine cytokine protein array (RayBiotech Inc., Norcross, GA, USA) for simultaneous detection of
G-CSF, granulocyte-macrophage colony-stimulating factor (GM-CSF), interleukin (IL)-2, IL-3, IL-4, IL-5, IL-6, IL-9, IL-10, IL-12 (p40), IL-12 (p70), IL-13, IL-17, interferon (IFN)- $\gamma$, monocyte chemoattractant protein (MCP)-1, MCP-5, regulated upon activation normal T cell expressed and secreted (RANTES), stem cell factor, tumor necrosis factor (TNF)- $\alpha$, soluble TNF- $\alpha$ receptor-1, thrombopoietin, and vascular endothelial growth factor was used to analyze the expression profile of MCE301 cells by following the manufacturer's instructions. The MCE301 culture supernatants were collected after $48 \mathrm{~h}$ of the culture with or without stimulation with $100 \mu \mathrm{g} \mathrm{ml}^{-1}$ of HET. Each array membrane was incubated with blocking buffer at room temperature for $30 \mathrm{~min}$ to block nonspecific binding. One milliliter of the cell culture supernatant was incubated with each membrane at room temperature for $2 \mathrm{~h}$. Then the membrane was incubated with a solution containing mixed biotinylated detection antibodies (anti-cytokine and anti-chemokine) for $1 \mathrm{~h}$. Horseradish peroxidase (EC 1.11.1.7)-conjugated streptavidin was then added and incubated for $45 \mathrm{~min}$. The membrane was washed, incubated with the ECL chemiluminescence detection agent (Amersham Bioscience, Little Chalfont, United Kingdom) for $1 \mathrm{~min}$, and exposed 
to Hyperfilm (Amersham Bioscience). The spot images were scanned, and each spot was measured by using the NIH Image-J software. The signals from negative control spots were used as the background level. The density of expression of each protein was observed as the intensity of the spot after subtraction of the background level. The relative level of expression of each protein was calculated by determining the percentage of the protein spot density based on the mean density of the positive control spots in each array. An increase of $\geq 2$-fold in the level of the expression of each cytokine after HET stimulation was considered as significant.

\section{Enzyme-linked Immunosorbent Assay for G-CSF}

Enzyme-linked immunosorbent assay (ELISA) kits for murine G-CSF was obtained from R\&D systems (Minneapolis, MN, USA). The tests were performed according to the supplier's instruction manuals.

\section{Isolation of Colonic Epithelial Cells}

Primary murine colonic epithelial cells were isolated from $\mathrm{C} 3 \mathrm{H} / \mathrm{HeJ}$ mice (6 weeks old) using a modification of previously described procedure (18). In brief, the colon was removed and washed four times with Hanks' balanced salt solution (HBSS) and supplemented with $100 \mathrm{Uml}^{-1}$ penicillin, and $100 \mu \mathrm{g} \mathrm{ml}^{-1}$ streptomycin. Segments of tissue were then incubated for $60 \mathrm{~min}$ at $37^{\circ} \mathrm{C}$ in $10 \mathrm{ml}$ of DMEM containing $100 \mathrm{mg}$ Dispase I (EC 3.4.24.4, Invitrogen, Carlsbad, CA, USA) in a $50 \mathrm{ml}$ centrifuge tube with constant gentle rotation. The digest was then passed through a steel mesh sieve to remove mucus and undigested fragments of the tissue. The recovered cells were then washed three times with HBSS by centrifugation at $1500 \mathrm{rpm}$ for $5 \mathrm{~min}$. The macrophages were depleted by panning from the suspension of cells at $37^{\circ} \mathrm{C}$ for $1 \mathrm{~h}$ on a $10 \mathrm{~cm}$ diameter Petri dish (Falcon 3003, Becton Dickinson, Franklin Lakes, NJ, USA). Non-adherent cells were collected and re-suspended in DMEM-FBS and loaded onto $4 \mathrm{ml}$ of $25 \%$ Precoll solution in a $15 \mathrm{ml}$ centrifuge tube. Tube was spun at $1500 \mathrm{rpm}$ for $30 \mathrm{~min}$ at room temperature, and the cells of interface layer were recovered. The cells were washed twice with DMEM-FBS to remove the Percoll. Isolated epithelial cells $\left(1 \times 10^{6}\right.$ cells $)$ were plated onto 96-well culture plate (Falcon 3072), and then cultured with or without HET. The contamination of lymphocytes and macrophages, which were determined by flow cytometry using FITC-labeled anti-CD3 Ab (clone 145-2C11), PE-labeled anti-CD45R/B220 Ab (RA3-6B2) and PE-labeled anti-CD11b Ab (M1/70), was less than $1.0 \%$.

\section{Fractionation of HET}

Fractionation of HET was performed according to previously described procedure (19). In brief, HET was fractionated into five fractions by methanol extraction, water extraction, dialysis and ethanol precipitation.

\section{Periodate Oxidation of F-5}

The procedure was performed as described previously (19). In brief, $1 \mathrm{~g}$ of F-5 was dissolved in $250 \mathrm{ml}$ of $50 \mathrm{mM}$ acetate buffer ( $\mathrm{pH} 4.5)$, and then $75 \mathrm{mM}$ sodium periodate $(250 \mathrm{ml})$ was added. After the reaction mixture was incubated at $4{ }^{\circ} \mathrm{C}$ in the dark for $96 \mathrm{~h}, 1 \mathrm{ml}$ of ethylene glycol was added to destroy excess periodate and then the mixture was dialyzed against water for $96 \mathrm{~h}$. Nondialyzable solution was concentrated to $10 \mathrm{ml}$, and $10 \mathrm{mg}$ of sodium tetrahydridoborate was added to the concentrate. The reaction mixture was stirred for $12 \mathrm{~h}$ at room temperature, and then neutralized with acetic acid. Finally, the oxidized product was obtained as a lyophilizate after dialysis. The yield of oxidized F-5 from F-5 was $56.5 \%$.

\section{Amylase Digestion of F-5}

One gram of F-5 was dissolved in $500 \mathrm{ml}$ of $50 \mathrm{mM}$ acetate buffer ( $\mathrm{pH}$ 5.0) containing $2 \mathrm{mM}$ calcium acetate, and then 900 Unit of $\alpha$-amylase (Bacillus subtilis, $\alpha-1,4$-glucan-4-glucanohydrolase; EC 3.2.1.1, SEIKAGAKU Co., Tokyo, Japan) and 1000 Unit of $\beta$-amylase (sweet potato, $\alpha$-1,4-glucan maltohydrolase; EC 3.2.1.2, SEIKAGAKU Co.) were added, and then incubated for $72 \mathrm{~h}$ at $37^{\circ} \mathrm{C}$. After neutralization with $1 \mathrm{M}$ sodium hydroxide, the reaction mixture was boiled to destroy the enzymes. The amylase digested F-5 was obtained as a lyophilizate after dialysis. The yield of amylase digested F-5 from F-5 was 46.4\%.

\section{Analytical Methods}

Total carbohydrate, uronic acid and protein contents were determined by phenol- $\mathrm{H}_{2} \mathrm{SO}_{4}$ (20), $m$-hydroxybiphenyl (21) and Bradford's methods (22) with Bio-Rad dye (Bio-Rad, Hercules, CA, USA) by using galactose, galacturonic acid and bovine serum albumin (BSA) as the respective standards. Component sugars of the samples were analyzed as trimethylsilyl methylglycoside derivatives by gas-liquid chromatography (23) on a DB-1 capillary column $(0.25 \mathrm{~mm}$ i.d. $\times 30 \mathrm{~m}, 0.2 \mu \mathrm{m}$ film thickness, J\&W Scientific, CA, USA); the temperature program was: $60^{\circ} \mathrm{C}$ for $1 \mathrm{~min}, 60-170^{\circ} \mathrm{C}\left(30^{\circ} \mathrm{C} \mathrm{min}^{-1}\right)$, $170-190^{\circ} \mathrm{C}\left(1^{\circ} \mathrm{C} \mathrm{min}^{-1}\right)$, and $190-300^{\circ} \mathrm{C}\left(30^{\circ} \mathrm{C} \mathrm{min}^{-1}\right)$.

\section{Statistical Analysis}

Data were expressed as mean $\pm \mathrm{SD}$, and differences between groups were analyzed by Student's $t$-test, and by analysis of variance (ANOVA) followed by post hoc analyses using Bonferroni/Dunn and Scheffe's test using 
A

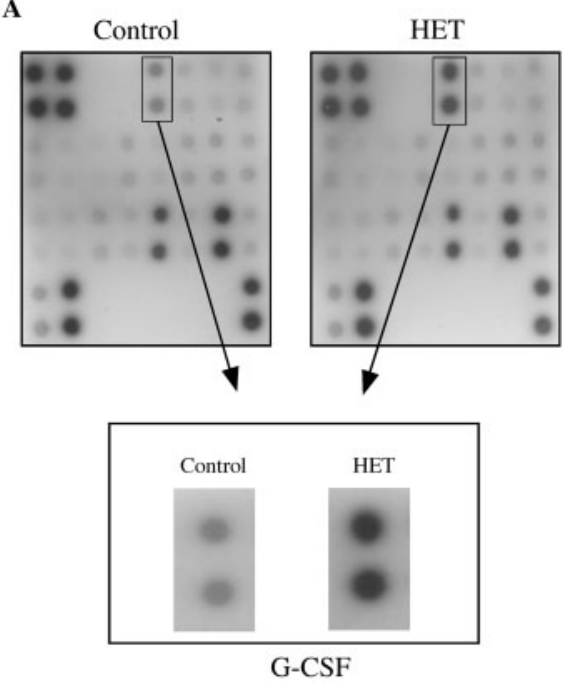

B

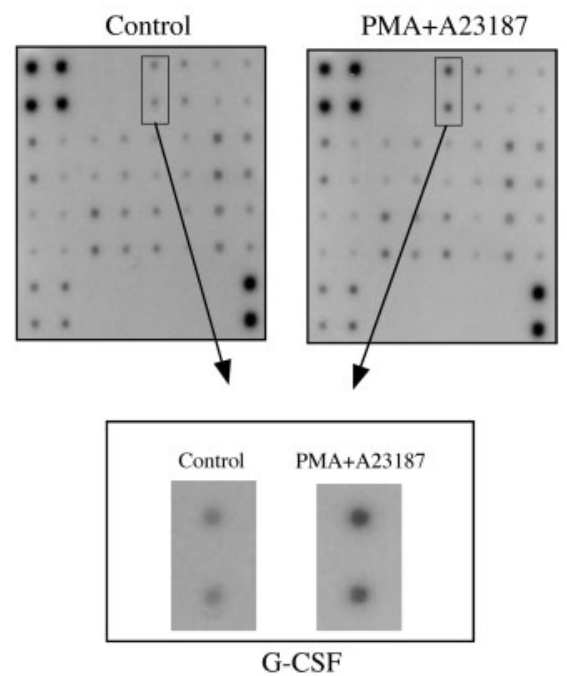

Figure 2. Protein array analysis of cytokines secretion from MCE301. (A) MCE301 cells were cultured for $48 \mathrm{~h}$ with or without $100 \mu \mathrm{g} \mathrm{ml} \mathrm{l}^{-1}$ of $\mathrm{HET}$, and the resulting culture supernatant was analyzed by cytokine protein array. The image of spot signal on membrane due to each cytokine was shown. (B) MCE301 cells were stimulated with PMA $(100 \mathrm{nM})$ plus A23187 $(100 \mathrm{nM})$ as a positive control. Note: detailed information on the cytokine protein array used in this study can be obtained following web site. http://www.raybiotech.com/index.asp? $\mathrm{m}=1$.

a personal computer with the StatView-J program for Macintosh (SAS Institute Inc., Cary, NC, USA). The probability $(P)$ values $<0.05$ were considered significant.

\section{Results}

\section{Protein Array Analysis on Cytokine Secretion from Murine Normal Colonic Epithelial Cell-Line MCE301 Cells}

In order to evaluate whether HET modulates the cytokine secretion of intestinal epithelial cells, the cytokines in the culture supernatant of the murine colonic epithelial cell line MCE301 cells were analyzed by the cytokine protein array. When MCE301 cells were cultured in the presence of HET, significantly increased intensity of the spot of G-CSF was observed (Fig. 2A), and the intensity of the spot was increased 2.5 -fold compared with that of unstimulated vehicle control. No measurable change in the intensity of the spot of other tested cytokines including GM-CSF was observed on the array (Fig. 2A). When MCE301 cells were stimulated with PMA plus A23187, which was used as a positive control, enhanced secretions of G-CSF was observed (Fig. 2B).

\section{Enhancement of G-CSF Secretion from Murine Normal Colonic Epithelial Cell-Line MCE301 Cells}

When MCE301 cells were stimulated with HET, the G-CSF secretion from MCE301 cells was enhanced in dose- and time-dependent manners (Fig. 3A and B).
To determine whether the enhanced G-CSF secretion by HET was attributable to enhanced G-CSF gene transcription, mRNA was isolated from MCE301 cells stimulated with HET for $24 \mathrm{~h}$, and then expression of G-CSF mRNA measured by RT-PCR. The enhanced G-CSF gene transcription by the stimulation of HET was observed (Fig. 3C and D). These results suggest that the G-CSF expression in response to HET is regulated, at least partially, at the transcriptional level.

\section{Enhancement of G-CSF Secretion from Primary Cultured Murine Colonic Epithelial Cells}

When primary cultured murine colonic epithelial cells from $\mathrm{C} 3 \mathrm{H} / \mathrm{HeJ}$ mouse were stimulated with $\mathrm{HET}$, the enhanced G-CSF secretion from the cells was observed (Fig. 4). These results suggest that HET also stimulates the secretion of G-CSF from intestinal epithelial cells.

\section{Active Ingredient in HET for the G-CSF Secretion Enhancing Activity}

HET was fractionated into five fractions by methanol extraction, water extraction, dialysis and ethanol precipitation in order to divide it into the fractions containing low molecular weight ingredients, intermediate-size ingredients and high molecular weight ingredients (Fig. 5A). Of these fractions, only the high molecular weight polysaccharide fraction (F-5) showed the G-CSF secretion enhancing activity (Fig. 5B), and the other fractions did not show any activity (Fig. 5B). F-5 was composed of about $105.3 \%$ of carbohydrate as galactose, which mainly comprised arabinose, galactose, glucose 

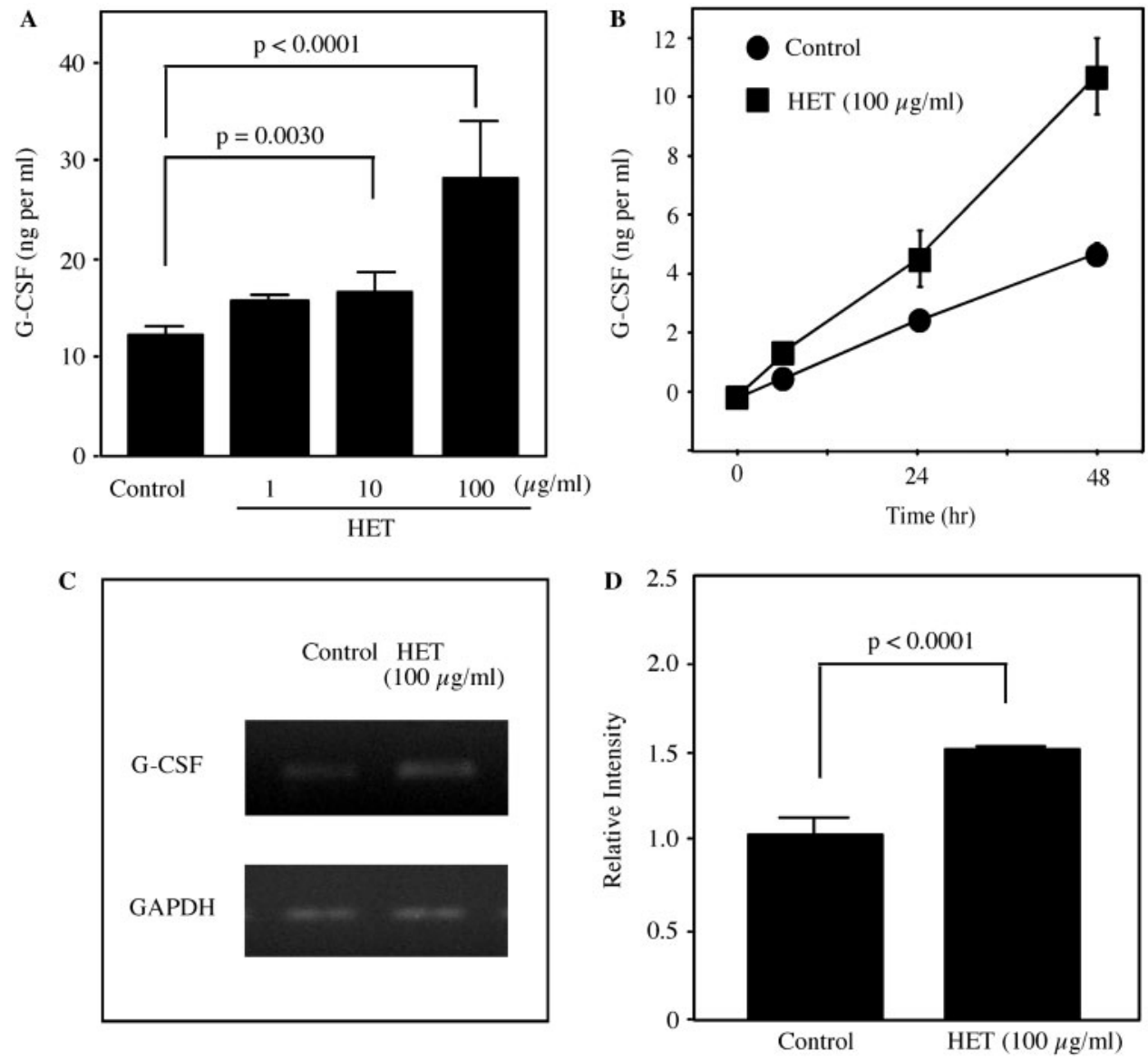

Figure 3. Enhanced secretion of G-CSF from MCE301 cells by HET stimulation. (A) Dose-dependent increased in production of G-CSF induced by HET. MCE301 cells were cultured in 24-well culture plate for $48 \mathrm{~h}$ with 1,10 or $100 \mu \mathrm{g} \mathrm{ml}^{-1}$ of HET, and the G-CSF content in the supernatant was measured using an ELISA for murine G-CSF. Data were expressed as mean $\pm \mathrm{SD}(n=3)$, and analyzed by ANOVA followed by post hoc analysis using Bonferroni/Dunn test. (B) Time-dependent increase in production of G-CSF induced by HET. MCE301 cells were cultured with or without stimulation with $100 \mathrm{\mu g} \mathrm{ml}^{-1}$ of HET in a 12-well culture plate, and the MCE301 culture supernatants were collected after 3, 6, 9, 24 or 48 h of culture, and then the G-CSF content was measured using an ELISA. Data were expressed as mean \pm SD $(n=4)$. (C) PCR product for each cytokine on a $1.5 \%$ agarose gel. (D) Expression of mRNA of G-CSF relative to GAPDH expression. G-CSF mRNA expression at time zero and $24 \mathrm{~h}$ after HET stimulation $\left(100 \mu \mathrm{g} \mathrm{ml}^{-1}\right)$. The relative level of G-CSF mRNA was calculated by NIH Image $\mathrm{J}$, and the values were expressed as pixel value (right panel). Data were expressed as mean $\pm \mathrm{SD}(n=4)$, and analyzed by Student's $t$-test.

and galacturonic acid, in addition to $7.5 \%$ of protein as BSA (Table 1). In order to clarify which molecules in F-5 contribute to the expression of the G-CSF secretion enhancing activity, the F-5 fraction was treated with periodate (chemical degradation of carbohydrate moiety) or amylase (enzymatic digestion of amylose moiety), and the G-CSF secretion enhancing activity of each product was compared with that of the untreated F-5. Chemical properties of F-5 modified by chemical and enzymatic treatments were shown in Table 2. The enhancing activity of F-5 on G-CSF secretion disappeared after periodate oxidation of F-5 (Fig. 6), whereas the activity of F-5 was increased significantly by amylase digestion of F-5 (Fig 6). These observations suggest that polysaccharide(s) is one of active ingredients of HET, and the heteropolysaccharide(s) other than amylose type polysaccharide(s) plays an important role in expression of the activity.

\section{Discussion}

It has been reported that G-CSF is produced by many different types of cells such as stimulated monocytes/ macrophages, lymphocytes, endothelial cells and fibroblasts (24). It has also been reported that human colonic adenocarcinoma HT-29 cells secreted G-CSF when stimulated with IL-1 $\beta$ and TNF- $\alpha$ (25). In the present study, it was shown that the HET-enhanced G-CSF secretion from primary cultured colonic epithelial cells and normal colonic epithelial cell-line MCE301 cells. So far as we know, this is a first description that the normal intestinal epithelial cells secrete G-CSF after stimulation. The intestinal tract possesses a large area and the inner surface was covered by a number of the epithelial cells. Therefore, it is presumed that the intestinal epithelial cells may be one of major source of G-CSF in the body. 
Bacterial endotoxin, LPS is known as a G-CSF potent inducer (26). The enhanced G-CSF secretion by HET was also observed in primary cultured colonic epithelial cells from LPS-non-responder $\mathrm{C} 3 \mathrm{H} / \mathrm{HeJ}$ mice, it was suggested that this enhancing effect of HET is not dependent on LPS.

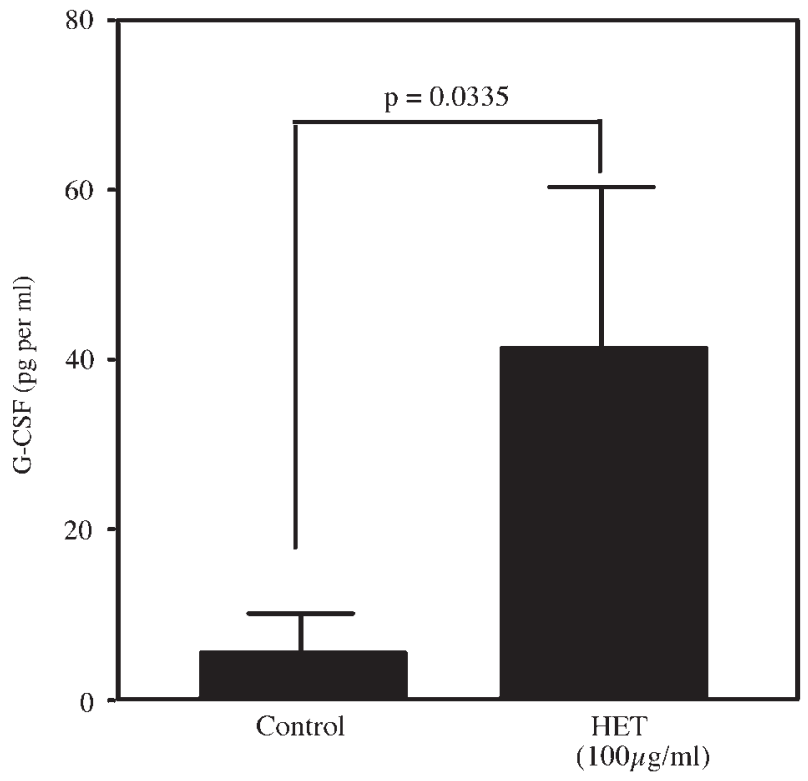

Figure 4. Enhanced secretion of G-CSF from colonic epithelial cells by HET. A primary cultured colonic epithelial cells from $\mathrm{C} 3 \mathrm{H} / \mathrm{HeJ}$ mouse were stimulated in 96-well culture plate for $24 \mathrm{~h}$ with or without $100 \mu \mathrm{g} \mathrm{ml}^{-1}$ of HET, and G-CSF content in the supernatant was measured using an ELISA for murine G-CSF. Data were expressed as mean $\pm \mathrm{SD}(n=3)$, and analyzed by Student's $t$-test.
In the present study, it was shown that the polysaccharide(s) in HET is responsible for the enhanced G-CSF secretion from intestinal epithelial cells, suggesting that polysaccharide(s) is one of important immunomodulating constituents in HET. HET consists of 10 component crude drugs, and contains a number of low molecular weight compounds (Fig. 1), which may possess immunomodulatory and immunosuppressive effects. Although low molecular fractions in HET did not show any G-CSF secretion enhancing activity (Fig. 5B), the complex interactions such as the synergistic or antagonistic effects among various ingredients including polysaccharide(s) would produce the pharmacological effects of HET as a whole. Thus, it is assumed the whole effect as a HET is absolutely not a simple sum of each effect induced by its constituents.

In a recent phase I clinical trial, Lehne et al. (27) reported the IgA concentration in saliva increased significantly following the oral administration of the soluble branched yeast $\beta$-1,3-d-glucan despite lack of systemic absorption of the polysaccharide. There are many reports that orally administered polysaccharides from plant, seaweed or fungus origin exert various pharmacological activities including immunomodulating activity (28-31). However, the mode of action of the polysaccharides including their target cells has been unclear because it has been widely believed that polysaccharides are not absorbed from digestive tract due to their high molecular weight (32). Therefore, it is important to clarify the detailed mode of action of the pharmacologically active polysaccharides on the modulating activity of intestinal immune system.
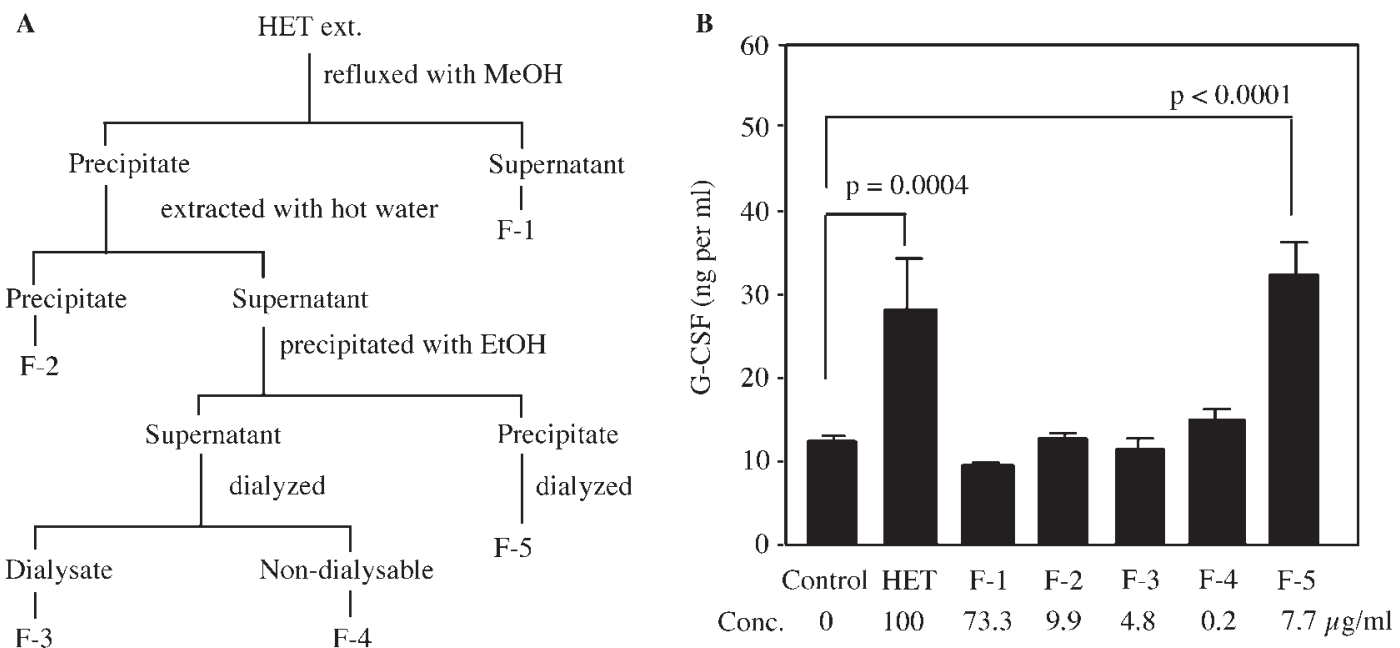

Figure 5. Fractionation of HET and the G-CSF secretion enhancing activity of the fractions from F-5. (A) A scheme of the fractionation of HET. HET was fractionated into five fractions by methanol extraction, water extraction, dialysis and ethanol precipitation. (B) G-CSF secretion enhancing activity of the fractions. MCE301 cells were cultured for $48 \mathrm{~h}$ in 24-well culture plate with HET or its fractions, and G-CSF content in the supernatant was measured using an ELISA. The concentration of each fraction for assay was calculated to be equivalent to $100 \mu \mathrm{g} \mathrm{ml}{ }^{-1}$ of $\mathrm{HET}$ from the sum of recover rate and the yield of each fraction. Data were expressed as mean $\pm \mathrm{SD}(n=3)$, and analyzed by ANOVA followed by post hoc analysis using Scheffe's test. 
Table 1. Chemical properties of sub fraction obtained from HET

\begin{tabular}{lrrrrr}
\hline & F-1 & F-2 & F-3 & F-4 & F-5 \\
\hline Recover rate (\% from TJ-41) & 65.9 & 8.9 & 4.4 & 0.2 & 6.9 \\
Carbohydrate content $^{\mathrm{a}}$ (\%) & n.d. & 65.2 & 63.2 & 41.9 & 105.3 \\
Uronic acid content $^{\mathrm{b}}(\%)$ & n.d. & 7.3 & 3.0 & 2.7 & 19.2 \\
Protein content $^{\mathrm{c}}$ (\%) & n.d. & 4.1 & 5.3 & 13.7 & 7.5 \\
Component sugar (mol\%) & & & & & \\
Arabinose & n.d. & 3.4 & 7.9 & 51.0 & 10.8 \\
Rhamnose & n.d. & 0.5 & 2.1 & 5.6 & 2.1 \\
Fucose & n.d. & 0.1 & Trace & Trace & 0.3 \\
Xylose & n.d. & 1.0 & 3.1 & 2.3 & 0.9 \\
Glucuronic acid & n.d. & 0.6 & 2.3 & 1.4 & 0.5 \\
Galacturonic acid & n.d. & 5.5 & Trace & 2.6 & 18.0 \\
Mannose & n.d. & Trace & Trace & 10.0 & Trace \\
Galactose & n.d. & 2.1 & 6.3 & 1.7 & 6.2 \\
Glucose & n.d. & 86.9 & 78.3 & 25.3 & 61.4 \\
\hline
\end{tabular}

n.d. Not determined.

${ }^{\mathrm{a}}$ Phenol-sulfuric acid method (as galactose); ${ }^{\mathrm{b}} m$-Hydroxybiphenyl method (as galacturonic acid); ${ }^{\mathrm{c}}$ Bradford method (as bovine serum albumin).

Table 2. Chemical properties of subfraction (F-5) modified by chemical and enzymic treatments

\begin{tabular}{lrcc}
\hline & F-5 & $\begin{array}{l}\text { Periodate } \\
\text { oxidized }\end{array}$ & $\begin{array}{l}\text { Amylase } \\
\text { treated }\end{array}$ \\
\hline Recover rate (\% from F-5) & - & 56.5 & 46.4 \\
Carbohydrate content $^{\mathrm{a}}(\%)$ & 105.3 & 37.9 & 62.7 \\
Uronic acid content $^{\mathrm{b}}$ (\%) & 19.2 & 4.2 & 29.9 \\
Protein content $^{\mathrm{c}}$ (\%) & 7.5 & 13.4 & 15.6 \\
Component sugar (mol\%) & & & \\
Arabinose & 10.8 & 11.6 & 16.3 \\
Rhamnose & 2.1 & 3.0 & 1.8 \\
Fucose & 0.3 & Trace & 0.3 \\
Xylose & 0.9 & 2.5 & 1.8 \\
Glucuronic acid & 0.5 & Trace & Trace \\
Galacturonic acid & 18.0 & 46.3 & 63.0 \\
Mannose & Trace & Trace & 1.7 \\
Galactose & 6.2 & 29.9 & 9.4 \\
Glucose & 61.4 & 6.6 & 5.7 \\
\hline
\end{tabular}

${ }^{\mathrm{a}}$ Phenol-sulfuric acid method (as galactose); ${ }^{\mathrm{b}} m$-hydroxybiphenyl method (as galacturonic acid); ${ }^{c}$ Bradford method (as bovine serum albumin).

The polysaccharide(s) in HET-enhanced G-CSF secretion from intestinal epithelial cells, suggesting that the intestinal epithelial cells act as one of the major target cells for the expression of immunopharmacological activity of the orally administered polysaccharides. However, whether orally active other polysaccharides modulate the cytokine secretion of intestinal epithelial cells, it is now not known.

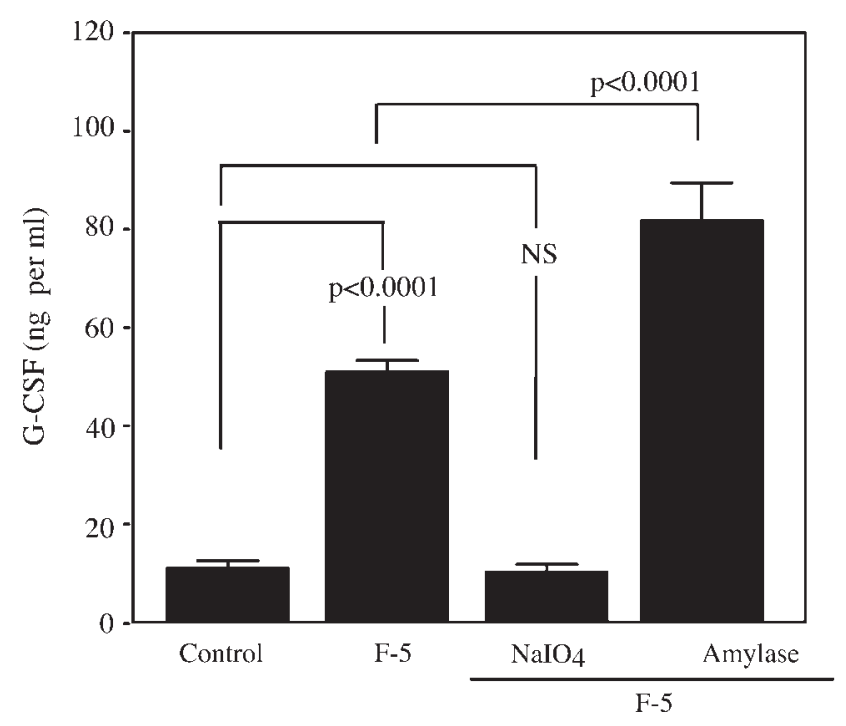

Figure 6. Effect of chemical and enzymatic treatments of F-5 on the G-CSF secretion enhancing activity of F-5. MCE301 cells were cultured in a 96-well culture plate with $100 \mu \mathrm{g} \mathrm{ml}^{-1}$ of periodate or amylase treated HET for $48 \mathrm{~h}$, and the G-CSF content in the supernatant was measured using an ELISA. Data were expressed as mean $\pm \mathrm{SD}(n=3)$, and analyzed by ANOVA followed by post hoc analysis using Scheffe's test.

G-CSF was identified initially as a growth factor for granulocyte, and characterized as a cytokine inducing both proliferation and maturation of granulocyte (33-36). There is growing evidence that G-CSF also exerts profound immunoregulatory effects in adaptive immunity (37-39). G-CSF induces regulatory $\mathrm{T}$ cells and regulatory dendritic cell (DC)-like cell (40-42). G-CSF modulates the balance between $\mathrm{T}$ helper 1 (Th1) and Th2 immune responses by affecting cytokine production (43-46). In addition, there is emerging data suggesting that G-CSF is a potential new agent for neuroprotection $(47,48)$. Thus, $\mathrm{G}-\mathrm{CSF}$ is considered as a pleiotropic cytokine playing a major role as regulators of hematopoiesis, innate and adaptive immune responses, etc. Therefore, the enhanced G-CSF secretion from intestinal epithelial cells by HET may contribute to the clinically observed various medicinal effects such as promoting the recovery of leucopenia after chemotherapy, reinforcement effect on resistance to infection, and improving allergic physical condition. Details of the G-CSF secretion enhancing activity of HET, including possible mode of action as well as active substances, are now underway, and it will be described in a following paper.

\section{Acknowledgements}

A part of this work was supported by a Grants-in Aid for Scientific Research from Japan Society for the Promotion of Science (grant ID: 18590660). We would like to thank Dr I. Sakakibara (Tsumura \& Co.) for analysis of 
HET by 3D-HPLC. We thank to $\mathrm{Mr} \mathrm{K}$. Nonaka, Ms H. Mizushima and Ms M. Inoue for their technical assistance.

\section{References}

1. Cho JM, Sato N, Kikuchi K. Prophylactic antitumor effect of Hochu-ekki-to (TJ-41) by enhancing natural killer cell activity. In vivo 1991;5:389-92.

2. Kataoka T, Akagawa KS, Tokunaga T, Nagao S. Activation of macrophages with Hochu-ekki-to. Jpn J Cancer Chemother 1989:16:1490-3.

3. Mori K, Kido T, Daikuhara H, Sakakibara I, Sakata T, Shimizu K, et al. Effect of Hochu-ekki-to (TJ-41), a Japanese herbal medicine, on the survival of mice infected with influenza virus. Antiviral Res 1999;44:103-11.

4. Kiyohara H, Nagai $T$, Munakata $K$, Nonaka $K$, Hanawa $T$, Kim SJ, et al. Stimulating effect of Japanese herbal (kampo) medicine, hochuekkito on upper respiratory mucosal immune system. Evid Based Complement Alternat Med 2006;3:459-67.

5. Matsumoto $T$, Noguchi $M$, Hayashi $O$, Makino $K$, Hochuekkito YH. A Kampo (traditional Japanese herbal) medicine, enhances mucosal IgA antibody response in mice immunized with antigen-entrapped biodegradable microparticles. Evid Based Complement Alternat Med; doi:10.1093/ecam/nem166.

6. McNabb PC. Host defense mechanisms at mucosal surfaces. Ann Rev Microbiol 1981;35:477-96.

7. Fujii Y, Shimada T, Koike T, Hosaka K, Tabei K, Namatame T, et al. Review article: regulation of TFF1 $(\mathrm{pS} 2)$ expression in gastric epithelial cells. Aliment Pharmacol Ther 2006;24 (Suppl 4): 285-91.

8. Andoh A, Fujiyama Y, Sakumoto H, Uchihara H, Kimura T, Koyama S, et al. Detection of complement C3 and factor B gene expression in normal colorectal mucosa, adenomas and carcinomas. Clin Exp Immunol 1998;111:477-83.

9. Cunliffe RN. Alpha-defensins in the gastrointestinal tract. Mol Immunol 2003;40:463-7.

10. Berin MC, McKay DM, Perdue MH. Immune-epithelial interactions in host defense. Am J Trop Med Hyg 1999;60 (4 Suppl): 16-25.

11. Blumberg RS, Terhorst C, Bleicher P, McDermott FV, Allan CH, Landau SB, et al. Expression of a nonpolymorphic MHC class I-like molecule, CD1D, by human intestinal epithelial cells. J Immunol 1991;147:2518-24.

12. Agace WW, Higgins JM, Sadasivan B, Brenner MB, Parker CM. T-lymphocyte-epithelial-cell interactions: integrin $\alpha_{\mathrm{E}}(\mathrm{CD} 103) \beta_{7}$, LEEP-CAM and chemokines. Curr Opin Cell Biol 2000;12:563-8.

13. Brandtzaeg P, Prydz H. Direct evidence for an integrated function of $\mathrm{J}$ chain and secretory component in epithelial transport of immunoglobulins. Nature 1984;311:71-3.

14. Balkwill FR, Burke F. The cytokine network. Immunol Today 1989;10:299-304.

15. Bellanti JA, Kadlec JV, Escobar-Gutierrez A. Cytokines and the immune response. Pediatr Clin North Am 1994:41:597-621.

16. Liles WC, Van Voorhis WC. Review: nomenclature and biologic significance of cytokines involved in inflammation and the host immune response. J Infect Dis 1995;172:1573-80.

17. Tabuchi Y, Ohta S, Arai Y, Kawahara M, Ishibashi K, Sugiyama N, et al. Establishment and characterization of a colonic epithelial cell line MCE301 from transgenic mice harboring temperature-sensitive simian virus 40 large T-antigen gene. Cell Struct Funct 2000;25:297-307.

18. Baumgart DC, Olivier WA, Reya T, Peritt D, Rombeau JL, Carding SR. Mechanisms of intestinal epithelial cell injury and colitis in interleukin 2 (IL2)-deficient mice. Cell Immunol 1998;187:52-66.

19. Yamada H, Kiyohara H, Cyong JC, Takemoto N, Komatsu Y, Kawamura $\mathrm{H}$, et al. Fractionation and characterization of mitogenic and anti-complementary active fractions from kampo (Japanese Herbal) medicine "juzen-taiho-to". Planta Med 1990;56:386-91.

20. Dubois M, Gilles KA, Hamilton JK, Rebers PA, Smith F. Colorimetric method for determination of sugars and related substances. Anal Chem 1956;28:350-6.
21. Blumenkranz N, Hansen GA. New method for quantative determination of uronic acid. Anal Biochem 1973;54:484-9.

22. Bradford MM. A rapid and sensitive method for the quantitation of microgram quantities of protein utilizing the principle of proteindye binding. Anal Biochem 1976;72:248-54.

23. York WS, Darvill AG, McNeil M, Stevenson TT, Albersheim P. Isolation and characterization of plant cell walls and cell-wall components. Methods Enzymol 1985;118:3-40.

24. Sallerfors B. Endogenous production and peripheral blood levels of granulocyte-macrophage (GM-) and granulocyte (G-) colonystimulating factors. Leuk Lymphoma 1994;13:235-47.

25. Calatayud S, Warner TD, Breese EJ, Mitchell JA. Relationship between endogenous colony stimulating factors and apoptosis in human colon cancer cells: role of cyclo-oxygenase inhibitors. $\mathrm{Br} J$ Pharmacol 2001;134:1237-44.

26. Nishizawa M, Nagata S. Regulatory elements responsible for inducible expression of the granulocyte colony-stimulating factor gene in macrophages. Mol Cell Biol 1990;10:2002-11.

27. Lehne G, Haneberg B, Gaustad P, Johansen PW, Preus H, Abrahamsen TG. Oral administration of a new soluble branched beta-1,3-D-glucan is well tolerated and can lead to increased salivary concentrations of immunoglobulin A in healthy volunteers. Clin Exp Immunol 2006;143:65-9.

28. Yamaoka Y, Kawakita T, Kaneko M, Nomoto K. A polysaccharide fraction of Zizyphi fructus in augmenting natural killer activity by oral administration. Biol Pharm Bull 1996;19:936-9.

29. Kim HY, Kim JH, Yang SB, Hong SG, Lee SA, Hwang SJ, et al. A polysaccharide extracted from rice bran fermented with Lentinus edodes enhances natural killer cell activity and exhibits anticancer effects. J Med Food 2007;10:25-31.

30. Yin Y, Fu W, Fu M, He G, Traore L. The immune effects of edible fungus polysaccharides compounds in mice. Asia Pac J Clin Nutr 2007;16 (Suppl 1): 258-60.

31. Kelly GS. Larch arabinogalactan: clinical relevance of a novel immune-enhancing polysaccharide. Altern Med Rev 1999;4:96-103.

32. Lorentsen KJ, Hendrix CW, Collins JM, Kornhauser DM, Petty BG, Klecker RW, et al. Dextran sulfate is poorly absorbed after oral administration. Ann Intern Med 1989;111:561-6.

33. Tsuchiya M, Asano S, Kaziro Y, Nagata S. Isolation and characterization of the cDNA for murine granulocyte colonystimulating factor. Proc Natl Acad Sci USA 1986;83:7633-7.

34. Nicola NA, Begley CG, Metcalf D. Identification of the human analogue of a regulator that induces differentiation in murine leukemia cells. Nature 1985;314:625-8.

35. Welte K, Bonilla MA, Gillio AP, Boone TC, Potter GK, Gabrilove JL, et al. Recombinant human granulocyte colonystimulating factor. Effects on hematopoiesis in normal and cyclophosphamide-treated primates. J Exp Med 1987;165:941-8.

36. Metcalf $\mathrm{D}$. The molecular control of cell division, differentiation, commitment and maturation in haematopoietic cells. Nature 1989;339:27-30.

37. Hadaya K, Kared H, Masson A, Chatenoud L, Zavala F. G-CSF treatment prevents cyclophosphamide acceleration of autoimmune diabetes in the NOD mouse. J Autoimmun 2005;24:125-34.

38. Mielcarek M, Martin PJ, Torok-Storb B. Suppression of alloantigen-induced $\mathrm{T}$-cell proliferation by $\mathrm{CD} 14+$ cells derived from granulocyte colony-stimulating factor-mobilized peripheral blood mononuclear cells. Blood 1997;89:1629-34.

39. Rutella S, Rumi C, Lucia MB, Sica S, Cauda R, Leone G. Serum of healthy donors receiving recombinant human granulocyte colonystimulating factor induces $\mathrm{T}$ cell unresponsiveness. Exp Hematol 1998;26:1024-33.

40. Kared H, Masson A, Adle-Biasette H, Bach JF, Chatenoud L, Zavala F. Treatment with granulocyte colony-stimulating factor prevents diabetes in NOD mice by recruiting plasmacytoid dendritic cells and functional $\mathrm{CD} 4+\mathrm{CD} 25+$ regulatory $\mathrm{T}$ cells. Diabetes 2005; 54:78-84.

41. Rutella S, Bonanno G, Pierelli L, Mariotti A, Capoluongo E, Contemi AM, et al. Granulocyte colony-stimulating factor promotes the generation of regulatory DC through induction of IL-10 and IFN- $\alpha$. Eur J Immunol 2004;34:1291-302.

42. Rutella S, Zavala F, Danese S, Kared H, Leone G. Granulocyte colony-stimulating factor: a novel mediator of $\mathrm{T}$ cell tolerance. J Immunol 2005;175:7085-91. 
43. Pan L, Delmonte J Jr, Jalonen CK, Ferrara JL. Pretreatment of donor mice with granulocyte colony-stimulating factor polarizes donor $\mathrm{T}$ lymphocytes toward type- 2 cytokine production and reduces severity of experimental graft-versus-host disease. Blood 1995;86:4422-9.

44. Sloand EM, Kim S, Maciejewski JP, Van Rhee F, Chaudhuri A, et al. Pharmacologic doses of granulocyte colony-stimulating factor affect cytokine production by lymphocytes in vitro and in vivo. Blood 2000;95:2269-74.

45. Boneberg EM, Hareng L, Gantner F, Wendel A, Hartung T. Human monocytes express functional receptors for granulocyte colony-stimulating factor that mediate suppression of monokines and interferon-gamma. Blood 2000;95:270-6
46. Hartung T, Docke WD, Gantner F, Krieger G, Sauer A, Stevens P, et al. Effect of granulocyte colony-stimulating factor treatment on ex vivo blood cytokine response in human volunteers. Blood 1995;85:2482-9.

47. Solaroglu I, Cahill J, Jadhav V, Zhang JH. A novel neuroprotectant granulocyte-colony stimulating factor. Stroke 2006;37:1123-8.

48. Schabitz WR, Kollmar R, Schwaninger M, Juettler E, Bardutzky J, Scholzke MN, et al. Neuroprotective effect of granulocyte colony-stimulating factor after focal cerebral ischemia. Stroke 2003;34:745-51.

Received October 22, 2007; accepted January 7, 2008 


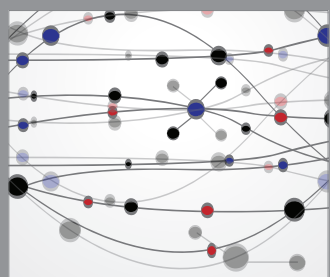

The Scientific World Journal
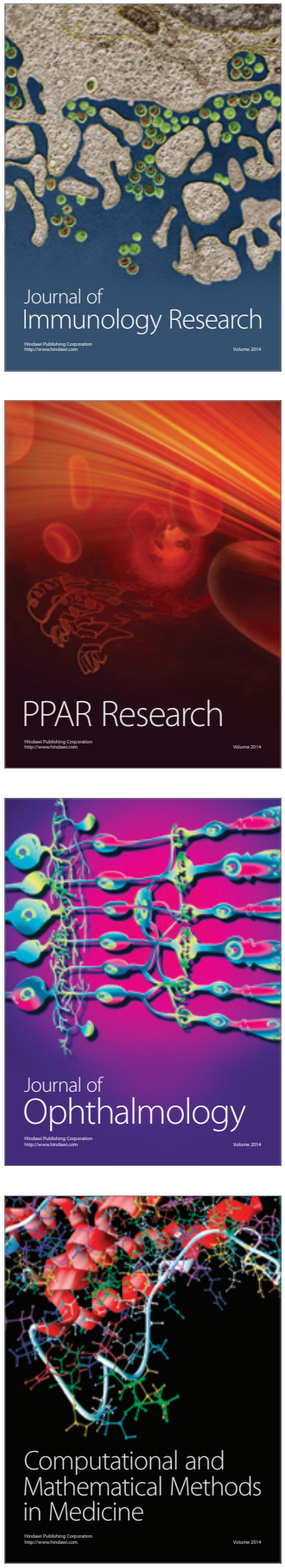

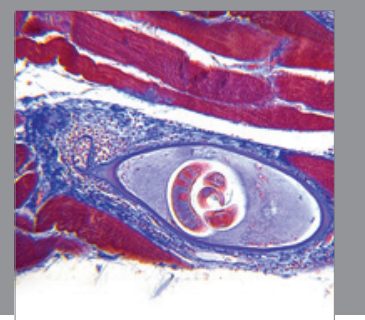

Gastroenterology

Research and Practice
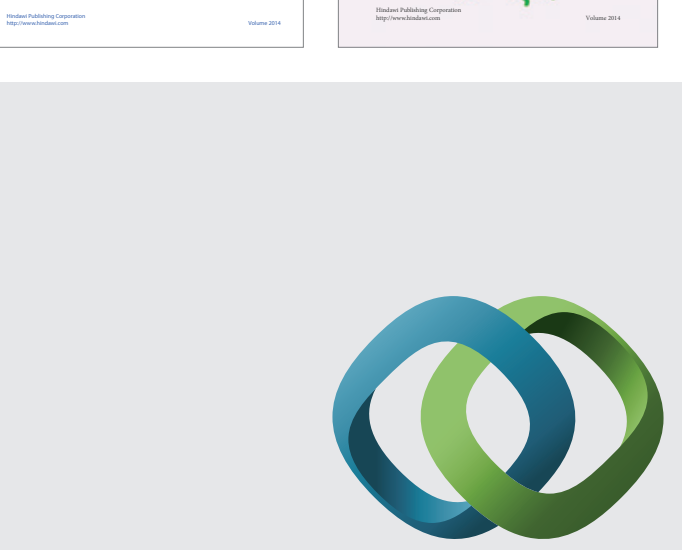

\section{Hindawi}

Submit your manuscripts at

http://www.hindawi.com
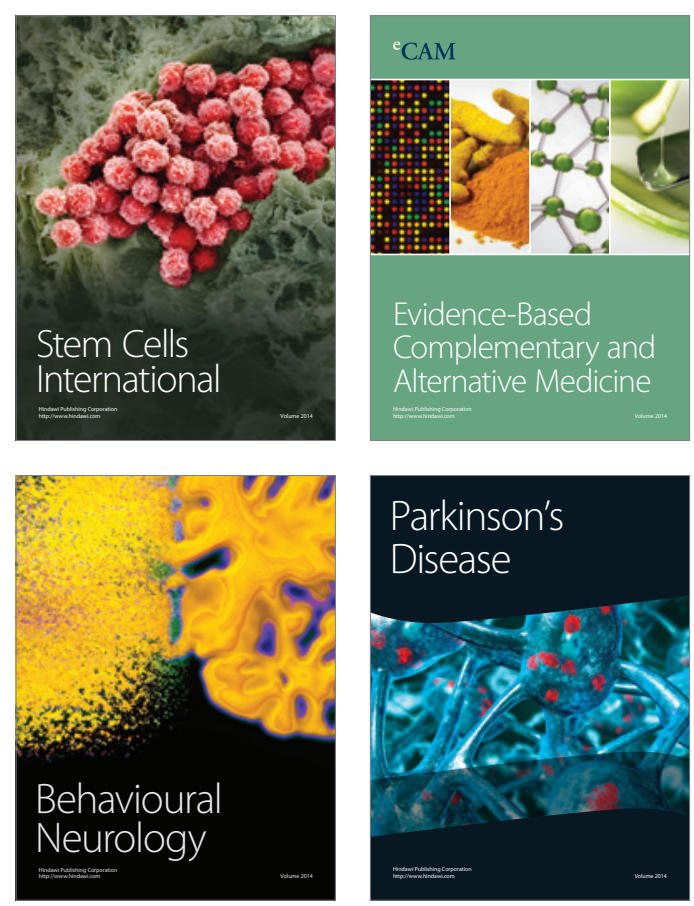

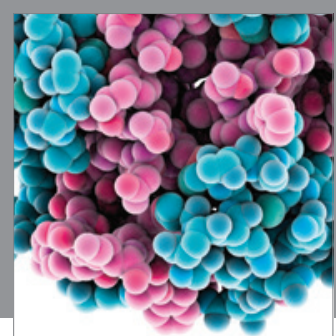

Journal of
Diabetes Research

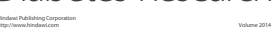

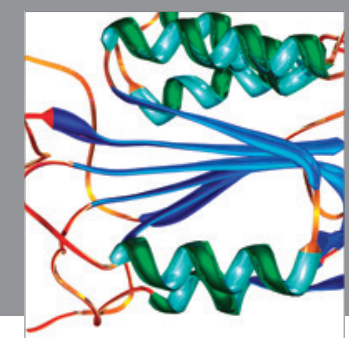

Disease Markers
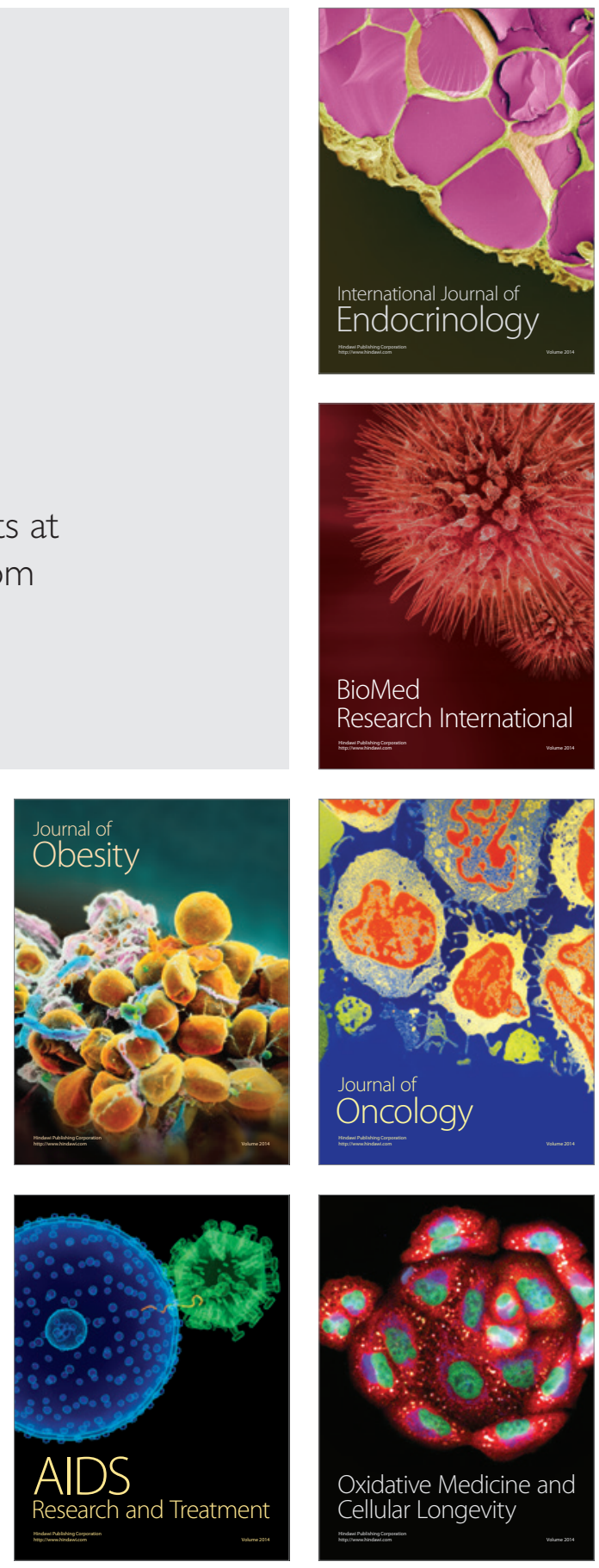